\title{
RSS and content syndication in higher education: subscribing to a new model of teaching and learning
}

\author{
Mark J.W. Lee*, Charlynn Miller and Leon Newnham \\ School of Information Technology and Mathematical Sciences, University of Ballarat, Australia
}

\begin{abstract}
While blogs, wikis and social networking sites are enjoying high levels of attention as tools to support learning, Really Simple Syndication (RSS) remains the "poor cousin" of these technologies in the higher education classroom, with relatively low uptake amongst educators and students. In this article, the authors argue that the affordances of RSS and content syndication can be used to deliver rich, active, social learning experiences that promote a high degree of learner personalisation, choice and autonomy. They describe a number of ways in which the potential of RSS can be exploited to transform pedagogy in ways that are congruent with emerging theories and models of learning, and that are consistent with the philosophy and ethos of Web 2.0 and networked society at large. The article concludes with a consideration of some of the issues and limitations facing the uptake and use of RSS for teaching and learning.
\end{abstract}

La «Syndication Vraiment Simple» (SVS) des contenus dans l'enseignement supérieur: l'adhésion à un nouveau modèle d'enseignement et d'apprentissage

Tandis que le Web 2.0 fait l'objet d'une grande attention comme outil d'appui à l'apprentissage, la «Syndication (mise en commun) Vraiment Simple(SVS) demeure le «parent pauvre» de ces technologies. On peut utiliser les services de la SVS et la mise à disposition des contenus pour fournir des situations d'apprentissage interpersonnel riches et actives qui suscitent un haut niveau de personnalisation, de choix et d'autonomie de la part de l'apprenant. On décrit un certain nombre de modes d'exploitation possibles du potentiel de la RSS pour transformer la pédagogie en harmonie avec les nouvelles théories et les modèles d'apprentissage en accord avec la philosophie et l'éthique de la société en réseau dans son sens le plus large.

RSS und Inhaltssyndication in höherer Bildung: das Unterstützen eines neuen Modells, zu lehren und zu lernen

Während Web 2.0 sich hoher Aufmerksamkeit als Werkzeug, das Lernen zu unterstützen erfreut, bleibt Really Simple Syndication der "arme Vetter" dieser Techniken. Der "Angebotscharakter" von RSS und Inhaltssyndication kann verwendet werden, um inhaltsreiche, aktive, soziale Lernerfahrungen zu liefern, die einen hohen Grad von Anfängerpersonalisierung hervorbringen, Wahlmöglichkeit und Autonomie fördern. Sie beschreiben eine Anzahl von Wegen, in denen das Potential von RSS benutzt werden kann, um Pädagogik so zu transformieren, dass sie mit neuen Theorien und Lernmodellen kongruent sind, Theorien und Modelle zu lernen, die mit der Philosophie und dem Ethos der allgemein vernetzten Gesellschaft übereinstimmen.

La «Sindicalización realmente simple» (SRS) de contenidos en la senseñanza superior: suscribiendo a un nuevo modelo de enseñanza y aprendizaje

Mientras la Web 2.0 está disfrutando de altos niveles de atención como herramienta de apoyo al aprendizaje,la «sindicalización» realmente simple (SRS) sigue siendo

*Corresponding author. Email: m.lee@ballarat.edu.au 
menospreciada en relación con esas tecnologías.Las capacidades de la SRS y de la sindicalización de contenidos pueden ser aprovechadas para suministrar experiencias de aprendizaje social ricas y activas que favorecen por parte del alumno un alto nivel de personalización ,de elección y de autonomía. Se describe algunas maneras de aprovechar el potencial de SRS para transformar la pedagogía en sintonía con las teorías y modelos de aprendizaje en vías de aparición y en conformidad con la filosofía y la ética de la sociedad en red en un sentido amplio.

Keywords: RSS; Web 2.0; content syndication; subscription; aggregation; podcasting

\section{Introduction}

Really Simple Syndication (RSS) is revolutionising the way we consume Web-based information, in particular dynamic content. RSS-enabled Websites generate a feed of eXtensible Markup Language (XML) data summarising the content of the site, which may be as diverse as news headlines, weather and stock market data, community-specific announcements or discussion board postings. Programs called aggregators periodically poll one or more subscribed feeds for updates and deliver or syndicate them directly to the user's desktop. RSS content can be filtered based on custom criteria, and content can be aggregated from across multiple feeds to suit the specific needs and interests of the user. RSS promises to be a time saver as the user does not have to manually plough through multiple sites for relevant content, nor is there a need for the tedious process of continually monitoring these sites for updates and additions.

According to EDUCAUSE (2007), “... [RSS] has the potential to become the primary vehicle through which users interact with the Internet" (p. 2, para. 4). Moreover, Hilton (2006) describes the unbundling of content, the shift from "provider push" to "demand pull" and the arrival of ubiquitous access to information and services, fuelled by RSS, as forces that will have a profound impact on the future of higher education. Although we are witnessing the proliferation of RSS feeds on the Web in general (Hrastnik, 2005; "RSS keeps booming", 2005), this technology has received comparatively low levels of attention and uptake as a pedagogical tool, especially as compared with other Web 2.0 and social software applications. The primary aim of this article is to explore the largely untapped potential of RSS as a catalyst for student-centred, social constructivist approaches to learning, to help meet the challenges and demands of higher education in the knowledge era. Drawing on extant literature and relevant educational theory, the authors highlight the possibilities of RSS that go beyond the dissemination of instructorgenerated content, while illuminating some of the problems and pitfalls, with the hope of establishing a starting point for others wishing to pursue further research and development in this area.

\section{RSS: a brief primer}

An RSS feed consists of a well-formed and valid document conforming to the XML 1.0 specification. The document is published on a Web server, and is maintained either manually through editing by hand, or more commonly, generated by server-side software. For example, many Web log (blog) and content management systems dynamically generate RSS.

An example of a valid RSS 2.0 document appears in Figure 1. At the document root is an $<$ rss $>$ element with a mandatory "version" attribute. Subordinate to this is a single $<$ channel $>$ element, which contains the channel's metadata as well as its contents in the form of $<$ item $>$ elements. Because RSS was developed to syndicate summaries of the content of 


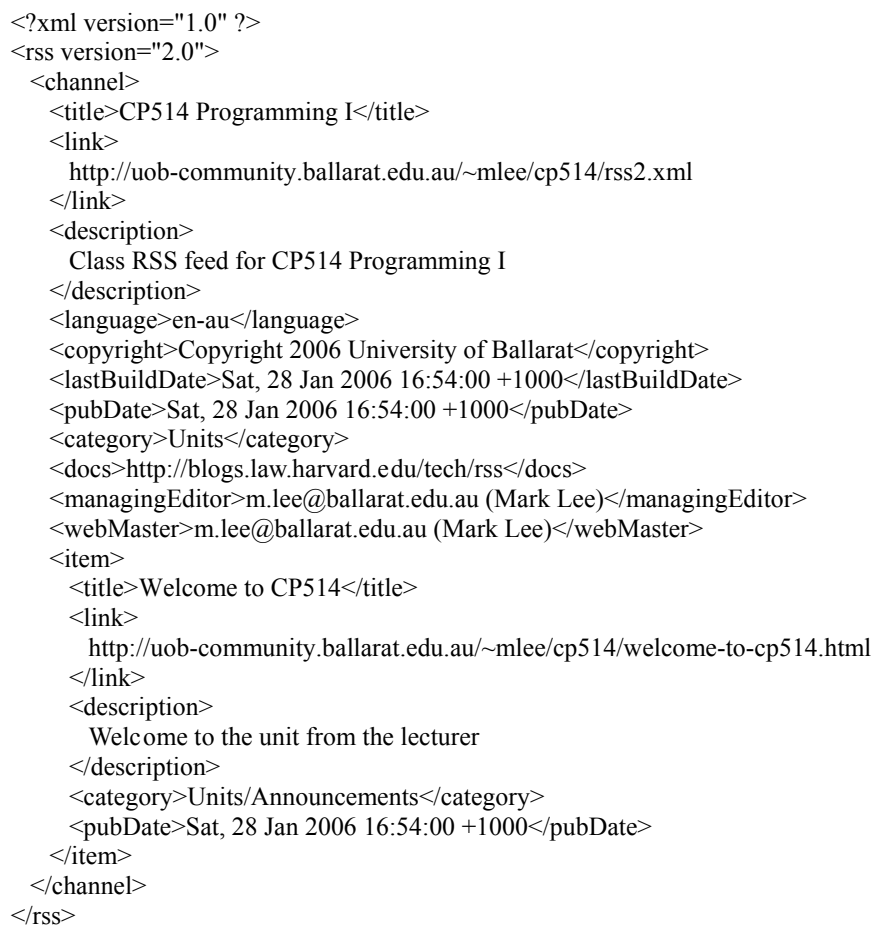

Figure 1. Example of an RSS 2.0 feed.

dynamic Websites such as newspapers or magazines, an item may represent a "story" or article; if so, the $<$ description $>$ contains a synopsis and the $<$ link $>$ points to the complete story. In the case of a blog, each item denotes a single blog entry or posting. An item may also be complete in itself rather than referring to a Webpage or other resource, in which case the description contains the text (entity-encoded HTML is allowed); the link and title may be omitted (RSS Advisory Board, 2005). Tables 1 and 2 contain an explanation of the elements seen in Figure 1.

On the client desktop, the aggregator program is configured by supplying it with the URL of the relevant RSS feed(s). The program monitors the feed(s) for new content and downloads it to the user's computer as it becomes available. With the advent of Web-based aggregators like Netvibes and Google Reader, based on server-side aggregation, feeds are polled and content downloaded to a server, rather than a client. Users carry out the tasks of subscribing to feeds as well as consuming feed content via a Web portal, which provides them with the ability to access their subscriptions using a Web browser from any Internetconnected computer.

Although often used very loosely, the term "podcasting", by definition, refers to the use of RSS technology to distribute digital audio content, often in the form of MPEG Layer 3 (MP3) files (Curry, 2004; Dixon \& Greeson, 2006). Podcasting-capable aggregators or "podcatchers" such as Apple's iTunes are used to monitor RSS 2.0 feeds for enclosures, which appear similar to the following:

<enclosure length="64837" type="audio/mpeg"

url=“http://uob-community.ballarat.edu.au/ mlee/cp514/podcast/week01.mp3”/> 
Table 1. Explanation of selected RSS $2.0<$ channel> sub-elements (adapted from RSS Advisory Board, 2005).

\begin{tabular}{llc}
\hline Element & Description & Required? \\
\hline title & $\begin{array}{l}\text { The name of the channel. If there is an HTML Web site that contains } \\
\text { the same information as the RSS file, the title of the RSS file should } \\
\text { match that of the Web site }\end{array}$ & Yes \\
link & The URL to the HTML Web site corresponding to the channel & Yes \\
description & Phrase or sentence describing the channel & Yes \\
language & The language the channel is written in & No \\
copyright & Copyright notice for channel content & No \\
lastBuildDate & The last time the content of the channel changed. Must conform to the & No \\
& $\quad$ Date and Time Specification of RFC 822, although the year may be \\
pubDate & expressed with two characters or four characters (four preferred) & \\
& The publication date-time for the content in the channel. Format & No \\
category & requirements are as for pubDate & No \\
docs & Specify one or more categories that the channel belongs to & No \\
& A URL that points to the documentation for the format used in the \\
managingEditor & RSS file & Email address of the person responsible for the feed content \\
webMaster & Email address of the person responsible for overseeing the technical & No \\
& aspects of the feed/channel & \\
\hline
\end{tabular}

The <enclosure $>$ element is a child element of $<$ item $>$, and contains a "url" attribute that provides the absolute or relative location of the MP3 file to be downloaded by the podcatcher, as well as "length" and "type" attributes that indicate the file size in bytes and MIME type respectively. The "audio/mpeg" MIME type is used for specifying MP3 files; this can be substituted with other types to facilitate the syndication of other forms of media (such as video in the case of "vodcasting").

Table 2. Explanation of selected RSS $2.0<$ item $>$ sub-elements (adapted from RSS Advisory Board, 2005).

\begin{tabular}{llc}
\hline Element & Description & Required?* \\
\hline title & The title of the item & No \\
link & The URL of the item & No \\
description & The item synopsis & No \\
author & E-mail address of the author of the item. In a collaborative blog, the & No \\
& author of an item may be different from the managing editor or & \\
& Webmaster of the channel & No \\
category & Includes the item in one or more categories. It has one optional & \\
& attribute, domain, a string that identifies a categorisation taxonomy. & \\
& The value of the element is a forward-slash-separated string that \\
& identifies a hierarchic location in the indicated taxonomy. Processors & \\
& may establish conventions for the interpretation of categories. There & \\
& is no limit to the number of category elements that may be included, \\
& for different domains. An item may also be cross-referenced in \\
different parts of the same domain & \\
pubDate & Indicates when the item was published. If this is a date-time in the & No \\
& future, aggregators may choose to not display the item until that date/ & \\
& time & \\
\hline
\end{tabular}

*All elements of an item are optional, however at least one of title or description must be present. 


\section{Benefits and current uses of RSS in higher education}

Several authors (e.g. Dieu \& Stevens, 2007; D’Souza, 2006; EDUCAUSE, 2007) have written about the potential educational benefits and uses of RSS. These include but are not limited to the following:

- The low cost and ubiquity of both the hardware and software required to produce and consume RSS content;

- The simplicity and ease of use of the technology and associated tools;

- The potential productivity gains for educators who adopt RSS, both as producers and consumers of content;

- The ability for students to skim new content quickly, reading in full only the material that they deem to be of interest or relevance;

- The ability for both students and educators to combine, re-mix and share information and feeds across various sources;

- Opportunities to emphasise to students the importance of drawing on multiple, diverse information sources;

- Opportunities to encourage students to make use of information and expertise from beyond the classroom.

According to Joly (2006), a number of universities have begun to integrate RSS feeds into their school Websites. For example, Duke University developed an RSS-powered Web portal called "Duke Today" to distribute news in law, medicine and science. The University of Iowa and University of Alabama use RSS to announce job openings and to provide updates on catalogued materials in their library system, respectively (Joly). However, the literature on the use of RSS for teaching and learning is relatively sparse. An extensive search by the authors revealed only a small number of publications containing case reports or empirical studies on the instructional or pedagogical uses of the technology. This stands in stark contrast to the burgeoning interest and steadily growing research on blogs and wikis in teaching and learning, despite the fact that RSS arguably pre-dates most other Web 2.0 technologies (Downes, 2004; Winer, 2004). It is also worth noting that podcasting - which, by definition, relies on RSS - is now well represented in the educational technology and elearning literature, with the term being used loosely to refer to MP3-based audio recordings, irrespective of the distribution mechanism.

Amongst published reports on the use of RSS for teaching purposes is the work of Glotzbach, Mohler and Radwan (2007), who describe a project involving a course at Purdue University entitled "Internet Foundations, Technologies and Development". An RSS feed was found to be an effective means of disseminating course announcements. Anecdotal data from the students suggested that they perceived the implementation as useful and having potential application in other courses. West, Wright, Gabbitas and Graham (2006) document their experience of using RSS in conjunction with blogs to promote reflective writing and student dialogue in an instructional technology course for pre-service teachers. Finally, Cold (2006) suggests that RSS can be used to improve both the effectiveness and efficiency of student research, with its ability to gather multiple sources in a single location and perform targeted searches. In addition to receiving course-related materials provided by the instructor, students are able to keep abreast with new research and developments related to their courses of study.

\section{Beyond transmissive learning approaches in the Web 2.0 era}

It appears that most existing uses of RSS and syndication services in higher education replicate traditional behaviourist models of teaching and learning, based on didactic and 
transmission-oriented approaches, whereby it is the teacher's responsibility to transfer or impart knowledge to students. In contrast, the largely untapped pedagogic potential of RSS appears to lie in its affordances for creating more collaborative learning environments. In the epistemology of social constructivism (McMahon, 1997; Vygotsky, 1962), knowledge and reality are viewed as being actively created in the minds of learners as a result of their participation in social relationships and interactions. The teacher's role is that of a partner or collaborator in the knowledge construction process, rather than holding an ontologically privileged position. The teacher and student both engage in the tasks of description, explanation, understanding, reflection and disclosure. Furthermore, interactions occur not only between teachers and students, but also amongst students in peer-to-peer relationships. Through syndication technologies, content and knowledge developed by a student learning community can be publicised and distributed (aggregated). In this way, syndication services may be seen as a collaborative tool that facilitates relationships between the pedagogy, the community members, the content they produce and other Web-based technologies.

Tangney, FitzGibbon, Savage, Mehan and Holmes (2001) argue for an expanded definition of social constructivism called "communal constructivism", which takes into account the synergy between recent advances in ICT (particularly those that are increasing our potential for communication and giving us the ability to store a variety of data types) and advances in virtual learning environments. In communal constructivism, students not only construct their own knowledge as a result of their interactions with others and with their environment, but also actively engage in the process of creating new knowledge for the good of others. Other authors echo this stance, maintaining that in today's knowledge society, in addition to acquiring knowledge and skills through interaction with experts such as their teachers (Lave \& Wenger, 1991), newcomers to a community of practice must also play a part in the ongoing advancement of the community (Lee, Eustace, Hay \& Fellows, 2005). RSS can be used to promote engagement in networked, collaborative idea generation and sharing, resulting in ever-growing repositories of knowledge that benefit all users and subscribers (D'Souza, 2006). In this way, RSS can be used to track discussions and conversation topics, wiki sites and articles, newsgroups and updates to traditional Websites, as well as to build connections between people with similar interests.

Connectivism (Siemens, 2005) is emerging as a new educational theory that attempts to accord with our changing information environment, and to reflect the social, interconnected and community-based characteristics of learning in contemporary times. Twenty-first century learning environments must take into account the networked nature of knowledge, opportunities afforded by teamwork and the importance of participation in knowledge generation in technology-rich environments (van Weert, 2006). Connectivism acknowledges the centrality of learning through the generation of ideas, supported by social activity, enabled by personal networks, interactivity and engagement in experiential tasks. It strives to overcome the limitations of behaviourism, cognitivism and constructivism by synthesising salient features and elements of several educational, social and technological theories and concepts. Like communal constructivism, connectivism takes social constructivism a step further, viewing the teacher as having the role of a mediator. Learning is the process of creating connections between nodes to form a network, a view that is congruent with the ways in which people engage in socialisation and interaction in the Web 2.0 world. A key idea is that learning starts with the connections that students make with one another, as opposed to with a fixed body of content. RSS, and more broadly, the concept of content syndication, have the potential to support complex, many-to-many connections in line with this philosophy. 


\section{Towards learner-centred applications of RSS: possible uses and scenarios}

In the subsections that follow, the authors offer a number of examples of applications underpinned by social constructivism, communal constructivism and connectivism that highlight the potential of Web content syndication services for higher education teaching and learning.

\section{RSS for personalised learning}

A Personal Learning Environment (PLE) (Attwell, 2007) may be broadly defined as an environment in which learners manage their own learning using various software and services. In contrast to an institutionally controlled learning management system, a PLE provides contextually appropriate toolsets by enabling individuals to adjust and select options based on their needs and circumstances, resulting in (ideally) a model where learner needs, not technologies, drive the learning process (Downes, 2005). In the PLE model, learning content is created and distributed in a very different manner to the traditional approach: Rather than being composed, organised and packaged, the content is syndicated. From there, it is re-mixed and re-purposed with the student's own individual application in mind, the finished product being fed forward to form the raw material for some other student's reading and use (Downes). In a PLE, a student is able to customise, control and shape his/her own "personal learning landscape" (Werdmuller \& Tosh, 2005), integrating multiple RSS feeds to allow for the aggregation of a range of multimedia content including text from blog entries, images, podcasts, videos (vodcasts), animations, SlideShare presentations, and so on.

RSS feeds may be offered at varying levels of granularity, thereby further enhancing learner choice and flexibility in specifying what content they wish to receive in their PLE to suit their needs and interests. For example, a university might offer a feed at the institution level to provide university-wide information; separate feeds might be established for each faculty, school, department or discipline, and by academics, researchers and students within these organisational units. Furthermore, a student's PLE may include subscriptions to a variety of feeds outside the institution at which he/she is formally enrolled, allowing him/ her to follow new and emerging trends and developments in his/her field of study - a key skill that university graduates will need to use in their professional lives.

\section{RSS for conversational learning, interaction and social networking}

RSS provides rich opportunities to enable the building of social networks and communities of practice that transcend the walls of the classroom or institution. McLoughlin, Brady, Lee and Russell (2007) used podcasting to support peer mentoring of pre-service teachers during their school-based teaching practicum, allowing them to interact with one another through the sharing of experiences, stories and anecdotes. It is thus possible for both teachers and students to become active producers and consumers ("prosumers") of asynchronous, voicebased discourse in an online community of practice. Such activities can become unwieldy or cumbersome for participants, given the copious volumes of multimedia content involved and the sporadic and unpredictable manner in which new material is generated. Syndication technologies like RSS reduce the complexity of receiving and organising content, enabling participants to attend to more pertinent tasks such as self-assessment, critical reflection and the provision of feedback to others.

Building on the work of Laurillard (2002), Sharples (2005) proposes a model in which learning occurs through the process of conversation. No distinction is made between people 
and interactive systems such as computers, with the advantage that the model can be applied both to human teachers and learners, as well as to technology-based teaching and learning support systems. In addition to supporting learner-learner interactions, "mashup" applications that combine data from disparate systems can take advantage of RSS to maintain awareness of data updates. In such instances, "users" of the feed are not people, but rather computer applications that are configured to subscribe to and receive content from the feed. Services such as Yahoo! Pipes and AlchemyPoint are powerful composition tools that can aggregate, manipulate and mashup content from different sources around the Web. In a scenario where a university has established feeds at each level of the organisation, individual students' and staff members' feeds may be "piped" into their respective disciplinary team or departmental feeds, which are then, in turn, fed into their parent organisational units (schools, faculties, colleges, etc.). In the same manner, some social networking sites like Facebook also incorporate RSS aggregation functionality that allows users to add feed subscriptions to their pages - a user can subscribe his/her profile page to his/her Flickr RSS feed; in this way, when he/she adds a new image on Flickr, that image is automatically added to his/her Facebook page.

\section{RSS for syndicating learner-generated content}

Learner-generated content is beginning to receive increased emphasis in a higher education climate where the value of textbooks is being questioned, and the open source and open content movements are beginning to receive significant levels of support and acceptance. Sener (2007) contends that a move towards content generation by students has the potential to change education for the better by increasing student engagement, developing critical thinking skills and fostering a sense of community. He claims that such processes can also result in products of lasting value to students individually, to other students, as well as to the wider community and society as a whole, a philosophy that is consistent with communal constructivism (Tangney et al., 2001).

Garrett and Nantz (2006) advocate the creation of distributed learning object syndication networks, where all participants are "prosumers" of reusable learning objects. Students participating in these networks become adept at creating and moving content and filtering and receiving information, and the new communication paradigm encourages them to view information from a new perspective. A similar type of strategy was implemented at Bentley College, where students in Frydenberg's (2006) IT Intensive course purchase Pocket PCs instead of textbooks, and explore technology concepts in a hands-on, learner-centred way. Participants form groups and work together to plan and produce video podcasts (vodcasts), for sharing through RSS. The students subscribe to the class feed via iTunes or a Pocket PC aggregator. This process may be viewed as a novel form of peer and reciprocal teaching, and serves a dual purpose, as students not only display their understanding of the course topics through the production of content, but also develop and exercise IT skills that are directly linked to the objectives of the course. Such innovative practices exemplify the expressions "user-generated content", "users add value" and "peers produce knowledge", reminders that with the help of Web 2.0 tools, appropriate learning activities can draw on participants' collective knowledge, enabling collaboration and the creation of shared artefacts.

\section{RSS for supporting authentic learning and assessment}

As a result of societal and technological changes, we are witnessing a blurring of the distinctions between informal and formal learning. At the same time, major social trends at work, 
such as the diversification of life trajectories, multiple career paths, re-skilling and flexible working hours are drivers of learning on demand. There is a need to expand our vision of pedagogy so that learning is a participatory, social process supporting personal life goals and needs. The use of RSS presents exciting prospects for authentic learning and assessment that are linked to or situated within students' employment and fieldwork contexts. The multimedia capabilities of mobile devices can be used to deliver text, audio, images and video to members of a distributed workforce in small, "bite-sized" pieces for just-in-time learning, such as in preparation for a real task in the workplace.

With the help of mobile devices and RSS, students can capture and disseminate content in the form of voice (podcasts), images (enhanced podcasts) and video (vodcasts) resulting from job tasks performed in situ within real or authentic workplace settings. This "performance content" (Boettcher, 2006) can be shared with the students' peers and instructors, who may provide assistance with and feedback on the tasks through opportunities for observation, correction and remediation.

\section{Barriers and limitations facing the use of RSS in higher education}

There appears to be a lack of knowledge about RSS amongst students and teachers, who may not be fully aware of the capabilities of the technology and the possibilities it presents. A survey of over 1,300 Americans conducted by the Pew Internet and American Life Project revealed that only $9 \%$ of Internet users knew of RSS feeds and understood the possibilities that they presented (Rainie, 2005). This statistic was only slightly higher for young adults, with $12 \%$ of US Internet users aged 18-29 possessing a working knowledge of what the term RSS means. Educators may need opportunities for professional development to reveal how RSS, in conjunction with other Web 2.0 applications, can support teaching and assessment. There is also a broader need to make time for awareness raising and discussion of what pedagogic approaches and technology-supported strategies best suit particular educational goals and learning outcomes.

Educators must also be cognisant that students may have fixed habits and patterns/behaviours in terms of the ways that they access the Internet and browse the Web. The model on which "Web 1.0" operates requires users to manually visit and search through Websites to find the content that they require. This is vastly different to the publish/subscribe model of RSS, which heralds a paradigmatic shift from producer push to demand pull (Hagel \& SeelyBrown, 2005; Dieu \& Stevens, 2007). Even with the diversity found in today's university students, many of the technologies used by these students cannot simply be considered uniform and universal (Kennedy, Judd, Churchward, Gray \& Krause, 2008). In the study by Glotzbach et al. (2007) alluded to earlier, the 240 students studying the Internet course at Purdue University were given a short introduction to RSS at the start of the semester, at which time it was determined that the majority had no previous knowledge of what an RSS feed was, despite the fact that many were majoring in a computing-related area. Comparisons between initial and end-of-semester surveys showed that at the conclusion of the course, participants showed an increased knowledge in RSS; however, the minimum weekly usage reported by respondents increased only marginally, demonstrating that students remained hesitant to adopt this technology as part of their daily online routine or regiment.

Furthermore, EDUCAUSE (2007) reminds us that although RSS is "[an] excellent mechanism for distributing regularly updated content" (p. 1, para. 5), "[n]ot all content is appropriate for RSS, such as a published article that is not going to change" (p. 2, para. 6). Educators may tend to use the technology to distribute relatively small amounts of largely static content over a single feed/source at fairly consistent intervals (e.g. weekly lectures 
in a single course/unit of study), as opposed to voluminous amounts of dynamic, timesensitive content across multiple feeds in a sporadic fashion. In such cases, there may not be a major incentive to take up RSS from the student's point of view, as the potential time savings to be gained from avoiding the need to manually check for new content may not seem to be worth the overhead required to set up an aggregator. While RSS is a low-cost, low-barrier technology, the provision of large numbers of feeds that provide the needed impetus or "critical mass" may be a stumbling block for many educators, and institutional commitment, endorsement or infrastructure may be lacking to support sustained uptake and use across departments and courses. In the aforementioned Purdue University study (Glotzbach et al., 2007), the researchers suggested that the low uptake could be due to the lack of activity on the RSS feed, as only a limited number of announcements were posted throughout the duration of the course. They predicted that there would be a positive correlation between the frequency and number of announcements and the number of students who use the RSS feed, but at the time of writing their paper had not collected data to substantiate this claim.

Finally, a key benefit of RSS is the ability for students to subscribe to and draw on sources that may be external to their universities or colleges, allowing them to benefit from the knowledge of a wide range of experts in industry and the wider community, as well as capitalising on the "wisdom of crowds" (Surowiecki, 2004) on the Internet. Such approaches may present challenges for educators and institutions, who will need to relinquish some degree of control and learn to look beyond the traditional view of classroom authority, accepting that in contrast to the "walled garden" approach of the LMS, they may not be able to regulate the feeds that students subscribe to, or the content that they receive through their aggregators. Moreover, Hilton (2006) describes the rise of the "pure property" view of ideas that may serve as an additional impediment to promoting the forms of open collaboration and sharing needed for such approaches to be successful.

\section{Conclusion}

Over time, as Web 2.0 tools and applications become even more ubiquitous in both mainstream society and in education, RSS and content syndication services are likely to become a significant part of students' personal knowledge management toolkits. Kennedy et al. (2008) argue that the degree to which students are using many emerging Web 2.0 technologies calls for further integration of these technologies into university curricula. This points to a future for the use of syndication services with podcasting and other tools as they begin to attain critical mass at an institutional and sector level, and as we arrive at a stage where there is a need for the delivery and organisation of content through subscription. The authors believe that in the long run, students and educators will need to adopt a more sustainable and efficient way to filter and manage the vast and continually growing volume of Webbased information.

Existing uses of RSS in education do not fully exploit its capabilities to facilitate complex teacher-learner and learner-learner interactions, as well as to act as a catalyst for collaborative knowledge building, sharing and exchange. "By enabling new channels of data exchange, as with research data and communities of learners, RSS has the potential to create a stronger connection between knowledge creation ... [and] individual learning" (EDUCAUSE, 2007, p. 2, para. 8). The applications described in this article are examples of how, if underpinned by appropriate pedagogical models, RSS and syndication technologies can assist educators in moving away from didactic modes of teaching and transmission of content, to enable greater student agency in the learning process, increased recognition 
that learner-generated content is a form of knowledge creation, and the development of peer-to peer learning. This is very much in line with the Web 2.0 movement, which emphasises active participation, collaboration and the creation and sharing of user-generated content and social media.

The examples presented also emphasise that RSS should not be viewed in a decontextualised fashion, or in isolation from other technologies and applications. In fact, syndication technologies may be seen as the conduit connecting or joining the various "pieces" in a Web 2.0 framework, what Lamb, Levine and Norman (2004) depict as "small technologies loosely joined". Many of the examples seen in this article are representative of microlearning (Lindner, 2006), or learning through relatively small learning units and short-term activities. Micro-learning processes derive from interaction with small, unbundled units of information that can be learnt and recombined, enabling greater relevance for learners and creating opportunities for just-in-time learning. In a wider sense, such trends are indicative of the way in which informal and incidental learning and knowledge acquisition are occurring through small chunks of content, as well as of the use of flexible technologies enabling learners to access the content and create new content easily, anywhere, on demand and on the move. The authors believe that RSS and syndication services will have an increasingly important role to play to this end.

\section{References}

Attwell, G. (2007). Personal Learning Environments - The future of eLearning? eLearning Papers, 2(1). Retrieved 14 January 2008, from http://www.elearningeuropa.info/out/?doc_id=9758\& rsr_id $=11561$

Boettcher, J.V. (2006, 28 February). The rise of student performance content. Campus Technology. Retrieved 10 January 2007, from http://www.campustechnology.com/article.aspx?aid=40747

Cold, S.J. (2006). Using Really Simple Syndication (RSS) to enhance student research. SIGITE Newsletter, 3(1), 6-9.

Curry, A. (2004). iPodder - A brief history. Retrieved 23 April 2005, from http://www.ipodder.org/ history

Dieu, B., \& Stevens, V. (2007). Pedagogical affordances of syndication, aggregation and mash-up of content on the Web. TESL-EJ, 11(1).

Dixon, C., \& Greeson, M. (2006). Recasting the concept of podcasting (Part I). Retrieved 20 September 2006, from http://news.digitaltrends.com/talkback109.html

Downes, S. (2004, June). RSS: grassroots support leads to mass appeal. Learning Circuits. Retrieved 8 May 2008, from http://www.learningcircuits.org/2004/jun2004/downes.htm

Downes, S. (2005, October). E-learning 2.0. ELearn. Retrieved 11 January 2006, from http:// www.elearnmag.org/subpage.cfm? section $=$ articles\&article $=29-1$

D'Souza, Q. (2006). RSS ideas for educators. (Ver. 1.1). Retrieved 7 June 2007, from http://www. teachinghacks.com/wp-content/uploads/2006/01/RSS\%20Ideas\%20for\%20Educators111.pdf

EDUCAUSE. (2007). 7 things you should know about ... RSS. Washington, DC: EDUCAUSE. Retrieved 22 February 2008, from http://net.educause.edu/ir/library/pdf/eli7024.pdf

Frydenberg, M. (2006). Principles and pedagogy: The two Ps of Podcasting in the Information Technology classroom. In D. Colton, W.J. Tastle, M. Hensel, \& A.A. Abdullat (Eds.), Proceedings of ISECON 2006 (\$3354). Chicago, IL: AITP.

Garrett, N., \& Nantz, K. (2006). RSS technologies and collaborative student learning communities. In T. Reeves \& S. Yamashita (Eds.), Proceedings of E-Learn 20006 (pp. 526-531). Chesapeake, VA: AACE.

Glotzbach, R.J., Mohler, J.L., \& Radwan, J.E. (2007). RSS as a course information delivery method. In Proceedings of the ACM SIGGRAPH 2007 educators program. Retrieved 2 May 2008, from ACM Digital Library.

Hagel, J., \& Seely-Brown, J. (2005). From push to pull: Emerging models for mobilising resources. Retrieved 9 December 2007, from http://www.johnseelybrown.com/pushmepull you4.72.pdf 
Hilton, J. (2006). The future for higher education: Sunrise or perfect storm. EDUCAUSE Review, $41(2), 58-71$.

Hrastnik, R. (2005). Slashdot survey predicts dramatic RSS growth, while RSS "wars" continue. Retrieved 31 December 2005, from http://rssdiary.marketingstudies.net/content/slashdot_ survey_predicts_dramatic_rss_growth_while_rss_wars_continue.php

Joly, K. (2006). RSS: The next big thing in university Web communications. Retrieved 22 January 2007, from http://www.universitybusiness.com/viewarticle.aspx?articleid=44

Kennedy, G.E., Judd, T.S., Churchward, A., Gray, K., \& Krause, K. (2008). First year students' experiences with technology: Are they really digital natives? Australasian Journal of Educational Technology, 24(1), 108-122.

Lamb, B., Levine, A., \& Norman, D. (2004). Small technologies loosely joined: Fast, cheap and out of control. Paper presented at the New Media Consortium 2004 Summer Conference, Vancouver, BC, 16-19 June.

Laurillard, D. (2002). Rethinking university teaching: A framework for the effective use of educational technology (2nd ed.). London: Routledge.

Lave, J., \& Wenger, E. (1991). Situated learning: Legitimate peripheral participation. Cambridge, England: Cambridge University Press.

Lee, M.J.W., Eustace, K., Hay, L., \& Fellows, G. (2005). Learning to collaborate, collaboratively: An online community building and knowledge construction approach to teaching computer supported collaborative work at an Australian university. In M.R. Simonson \& M. Crawford (Eds.), Proceedings of the 2005 AECT International Convention (pp. 286-306). North Miami Beach, FL: Nova Southeastern University.

Lindner, M. (2006). Use these tools, your mind will follow. Learning in immersive micromedia and microknowledge environments. In D. Whitelock and S. Wheeler (Eds.), Research proceedings of the 13th ALT-C conference (pp. 41-49). Oxford: ALT.

McLoughlin, C., Brady, J., Lee, M.J.W., \& Russell, R. (2007). Peer-to-peer: An e-mentoring approach to facilitating reflection on professional experience for novice teachers. Paper presented at the 2007 AARE Conference, Fremantle, WA, 25-29 November.

McMahon, M. (1997). Social constructivism and the World Wide Web: A paradigm for learning. In R. Kevill, R. Oliver, \& R. Phillips (Eds.), What works and why: Proceedings of the 14th ASCILITE Conference. Perth, WA: Curtin University of Technology.

Rainie, L. (2005). Public awareness of Internet terms. Washington, DC: Pew Internet \& American Life Project. Retrieved 22 January 2007, from http://www.pewinternet.org/pdfs/PIP_Data_ Techterm_aware.pdf

RSS Advisory Board. (2005). Really Simple Syndication: RSS 2.0.1 Specification. (Rev. 6). Retrieved 2 March 2006, from http://www.rssboard.org/rss-2-0-1-rv-6

RSS keeps booming. (2005, 25 September). BusinessWeek Online. Retrieved 22 January 2007, from http://www.businessweek.com/technology/tech_stats/rss050923.htm

Sener, J. (2007). Category:Student-Generated Content. Retrieved 10 March 2007, from http:// www.sloan-c-wiki.org/wiki/index.php?title=Category:Student-Generated_Content

Siemens, G. (2005). Connectivism: A learning theory for the digital age. International Journal of Instructional Technology and Distance Learning, 2(1), 3-10.

Sharples, M. (2005). Learning as conversation: Transforming education in the Mobile Age. Paper presented at Conference on Seeing, Understanding, Learning in the Mobile Age, Budapest, Hungary, 28-30 April.

Surowiecki, K. (2004). The wisdom of crowds. New York: Doubleday.

Tangney, B., FitzGibbon, A., Savage, T., Mehan, S., \& Holmes, B. (2001). Communal constructivism: Students constructing learning for as well as with others. In J. Price, D. Willis, N. Davies, \& J. Willis (Eds.), Proceedings of SITE 2001 (pp. 3114-3119). Norfolk, VA: AACE.

van Weert, T.J. (2006). Education of the twenty-first century: New professionalism in lifelong learning, knowledge development and knowledge sharing. Education and Information Technologies, $11(3 / 4), 217-237$.

Vygotsky, L.S. (1962). Thought and language. Cambridge, MA: MIT Press.

Werdmuller, B., \& Tosh, D. (2005). Elgg - A personal learning landscape. TESL-EJ, 9(2).

West, R.E., Wright, G., Gabbitas, B., \& Graham, C.R. (2006). Reflections from the introduction of blogs and RSS feeds into a pre-service instructional technology course. TechTrends, 50(4), 54-60.

Winer, D. (2004). RSS history (RSS 2.0 at Harvard Law). Retrieved 19 August 2008, from http:// cyber.law.harvard.edu/rss/rssVersionHistory.html 